\title{
TU/e EmonONEN

\section{Structurally simple supported platinum clusters prepared from [Pt15(CO)30]2- on magnesium oxide}

\section{Citation for published version (APA):}

Chang, J. R., Koningsberger, D. C., \& Gates, B. C. (1992). Structurally simple supported platinum clusters prepared from [Pt15(CO)30]2- on magnesium oxide. Journal of the American Chemical Society, 114(16), 64606466. https://doi.org/10.1021/ja00042a025

DOI:

10.1021/ja00042a025

Document status and date:

Published: 01/01/1992

\section{Document Version:}

Publisher's PDF, also known as Version of Record (includes final page, issue and volume numbers)

\section{Please check the document version of this publication:}

- A submitted manuscript is the version of the article upon submission and before peer-review. There can be important differences between the submitted version and the official published version of record. People interested in the research are advised to contact the author for the final version of the publication, or visit the $\mathrm{DOI}$ to the publisher's website.

- The final author version and the galley proof are versions of the publication after peer review.

- The final published version features the final layout of the paper including the volume, issue and page numbers.

Link to publication

\section{General rights}

Copyright and moral rights for the publications made accessible in the public portal are retained by the authors and/or other copyright owners and it is a condition of accessing publications that users recognise and abide by the legal requirements associated with these rights.

- Users may download and print one copy of any publication from the public portal for the purpose of private study or research.

- You may not further distribute the material or use it for any profit-making activity or commercial gain

- You may freely distribute the URL identifying the publication in the public portal.

If the publication is distributed under the terms of Article 25fa of the Dutch Copyright Act, indicated by the "Taverne" license above, please follow below link for the End User Agreement:

www.tue.nl/taverne

Take down policy

If you believe that this document breaches copyright please contact us at:

openaccess@tue.nl

providing details and we will investigate your claim. 


\title{
Structurally Simple Supported Platinum Clusters Prepared from $\left[\mathrm{Pt}_{15}(\mathrm{CO})_{30}\right]^{2-}$ on Magnesium Oxide
}

\author{
J.-R. Chang, ${ }^{\dagger}$ D. C. Koningsberger, ${ }^{\ddagger}$ and B. C. Gates ${ }^{*, \dagger}$ \\ Contribution from the Center for Catalytic Science and Technology, Department of Chemical \\ Engineering, University of Delaware, Newark, Delaware 19716, and Laboratory for Inorganic \\ Chemistry and Catalysis, Eindhoven University of Technology, \\ 5600 MB Eindhoven, The Netherlands. Received December 19, 1991
}

\begin{abstract}
A Longoni-Chini cluster, $\left[\mathrm{Pt}_{15}(\mathrm{CO})_{30}\right]^{2-}$, was prepared on $\mathrm{MgO}$ powder by a surface-mediated synthesis from $\mathrm{Na}_{2} \mathrm{PtCl}_{6}$ in the presence of $\mathrm{CO}$. The formation of $\left[\mathrm{Pt}_{15}(\mathrm{CO})_{30}\right]^{2-}$ and its decarbonylation at $120^{\circ} \mathrm{C}$ under vacuum were characterized by infrared and $\mathrm{X}$-ray absorption spectroscopies. The decarbonylated cluster had an average $\mathrm{Pt}-\mathrm{Pt}$ bond distance of 2.76 $\AA$ and an average Pt-Pt first-shell coordination number of 3.7, indicating that the trigonal prismatic framework structure of the Longoni-Chini cluster was retained after decarbonylation; thus the decarbonylated cluster is represented as $\mathrm{Pt}_{15} \mathrm{with}$ a trigonal prismatic structure. When this sample was recarbonylated, the Longoni-Chini cluster was not re-formed. The average $\mathrm{Pt}-\mathrm{Pt}$ bond distance increased to $2.78 \AA$ and the $\mathrm{Pt}-\mathrm{Pt}$ first-shell coordination number increased to 6.0 , indicating that a $\mathrm{CO}$-induced morphology change gave approximately hemispherical $\mathrm{Pt}$ clusters with adsorbed $\mathrm{CO}$.
\end{abstract}

\section{Introduction}

Structurally simple supported metals have been prepared from carbonyl clusters of Os, ${ }^{1} \mathrm{Ir}^{2}{ }^{2}$ and a few other metals, but not yet from those of Pt. Pt is the most important catalytic metal, being applied for automobile exhaust conversion, naphtha reforming, and many other reactions. Preparation of structurally simple supported catalysts from $\mathrm{Pt}$ carbonyl clusters is difficult (1) because Pt carbonyls are highly air sensitive and difficult to synthesize in high yields on support surfaces and (2) because Pt easily forms metallic aggregates of various sizes and shapes. A recent report ${ }^{3}$ of the high-yield synthesis of $\left[\mathrm{Pt}_{9}(\mathrm{CO})_{18}\right]^{2-}$ and of $\left[\mathrm{Pt}_{12}(\mathrm{CO})_{24}\right]^{2-}$ on the basic $\mathrm{MgO}$ surface and reports of simple decarbonylation of supported $\left[\mathrm{Os}_{10} \mathrm{C}(\mathrm{CO})_{24}\right]^{2-, 1}\left[\mathrm{HIr}_{4}(\mathrm{CO})_{11}\right]^{-2}$ and $\left[\mathrm{Ir}_{4}(\mathrm{CO})_{12}\right]^{4}$ suggest that $\mathrm{Pt}$ cluster carbonyl anions could be formed on a basic support and decarbonylated without loss of cluster nuclearity.

Here we report the surface-mediated synthesis of $\left[\mathrm{Pt}_{15}(\mathrm{CO})_{30}\right]^{2-}$ on $\mathrm{MgO}$, its decarbonylation (without loss of nuclearity), and its recarbonylation (with changes in nuclearity). The surface structures have been characterized by infrared and $X$-ray absorption spectroscopies.

\section{Results}

Characterization of Surface and Extracted Species by Infrared and Ultraviolet-Visible Spectroscopy. The solid formed by deposition of $\mathrm{Na}_{2} \mathrm{PtCl}_{6}$ on $\mathrm{MgO}$ followed by treatment in $\mathrm{CO}$ was yellow-green. The surface species were characterized by infrared spectroscopy and by extraction into solution. The adsorbed species could not be extracted with neutral solvents such as THF, but extraction with $[\mathrm{PPN}][\mathrm{Cl}]$ in THF was efficient, consistent with the occurrence of cation metathesis, which implies the presence of ionic species on the MgO surface. The yellow-green extract solution has infrared (Figure 1A) and ultraviolet-visible (Figure 2) spectra that are almost the same as those of $\left[\mathrm{Pt}_{15}(\mathrm{CO})_{30}\right]^{2-}$ (Table I), ${ }^{5-7}$ which is therefore identified as the organometallic species in the extract solution. The yield of $\left[\mathrm{Pt}_{15}(\mathrm{CO})_{30}\right]^{2-}$ in the one-step extraction, estimated from the absorbance at $706 \mathrm{~nm}$, was about $73 \%$.

The $\nu_{\mathrm{CO}}$ infrared spectrum of the surface species (Figure 1B) is almost the same as that of $\left[\mathrm{Pt}_{15}(\mathrm{CO})_{30}\right]^{2-}$ in THF solution, except that another peak is present, at $1853 \mathrm{~cm}^{-1}$. The comparison indicates that $\left[\mathrm{Pt}_{15}(\mathrm{CO})_{30}\right]^{2-}$ was the predominant organometallic species on the MgO surface.

Decarbonylation and Recarbonylation of Pt Clusters on $\mathrm{MgO}$. The infrared absorption bands of the platinum carbonyl species

\footnotetext{
* Corresponding author.

${ }^{+}$University of Delaware.

¥Eindhoven University of Technology.
}

Table I. IR and UV-Visible Data for $\left[\mathrm{Pt}_{15}\left(\mathrm{CO}_{30}\right)\right]^{2-}$ in Solutions and on Metal Oxide Supports

\begin{tabular}{llll}
\hline $\begin{array}{c}\text { solvent or } \\
\text { support }\end{array}$ & \multicolumn{1}{c}{$\nu_{\mathrm{CO}, \mathrm{cm}^{-1}}$} & $\begin{array}{c}\text { UV-visible } \\
\text { absorption, } \mathrm{nm}\end{array}$ & \multicolumn{1}{c}{ ref } \\
\hline $\mathrm{THF}$ & $2055 \mathrm{vs}, 1890 \mathrm{w}, 1870 \mathrm{~s}$, & & 5 \\
& $1840 \mathrm{w}, 1825 \mathrm{w}$ & & 8 \\
$\gamma-\mathrm{Al}_{2} \mathrm{O}_{3}$ & $2040 \mathrm{~s}, 1850 \mathrm{~s}$ & & 9 \\
$\gamma \cdot \mathrm{Al}_{2} \mathrm{O}_{3}$ & $2058 \mathrm{~s}, 1862 \mathrm{~s}$ & & this work \\
$\mathrm{MgO}^{\mathrm{THF}}$ & $2059 \mathrm{~s}, 1877 \mathrm{~s}, 1853 \mathrm{~s}$ & & this work \\
& $2055 \mathrm{vs}, 1894 \mathrm{w}, 1874 \mathrm{~s}$, & & \\
acetonitrile & $1845 \mathrm{w}$ & 410,700 & 6,7 \\
THF & & 406,706 & this work \\
\hline
\end{tabular}

${ }^{a}$ Species extracted from the solid following surface-mediated synthesis.

on $\mathrm{MgO}$ did not change in either intensity or position as the sample was heated under vacuum $\left(0.01-0.001\right.$ Torr) to $65^{\circ} \mathrm{C}$ (Figure $3 \mathrm{~A})$. The bridging $\mathrm{CO}$ band disappeared, and the intensity of the terminal $\mathrm{CO}$ absorption decreased to about one-third of the original value after $10 \mathrm{~min}$ at $75^{\circ} \mathrm{C}$ under vacuum (Figure 3B). After $30 \mathrm{~min}$ at $75^{\circ} \mathrm{C}$, the intensity of the terminal CO band had decreased to about $10 \%$ of its original value (Figure $3 \mathrm{C}$ ). The decarbonylation was complete after $30 \mathrm{~min}$ at $100^{\circ} \mathrm{C}$ under vacuum (Figure 3D).

After the sample had been cooled to room temperature, $\mathrm{CO}$ (flowing at $50-100 \mathrm{~mL} / \mathrm{min}$ at $1 \mathrm{~atm}$ ) was introduced into the cell. A band assigned ${ }^{3,8,9}$ to terminal $C O$ ligands adsorbed on highly dispersed $\mathrm{Pt}$ clusters appeared at $2064 \mathrm{~cm}^{-1}$ (Figure 3E). The spectrum of $\left[\mathrm{Pt}_{15}(\mathrm{CO})_{30}\right]^{2-}$ did not reappear.

$X$-ray Absorption Near Edge Structure (XANES). Pt $\mathrm{L}_{\mathrm{III}}$ absorption edge data are shown in Figure 4 for the supported $\mathrm{Pt}$ sample formed by decarbonylation of $\left[\mathrm{Pt}_{15}(\mathrm{CO})_{30}\right]^{2-}$ and for the sample formed by recarbonylation. The normalized $\mathrm{L}_{\text {III }}$ white-line intensity increased as a result of $\mathrm{CO}$ adsorption.

Extended X-ray Absorption Fine Structure (EXAFS) Reference Data. The EXAFS analysis for the supported $\mathrm{Pt}$ samples was based on phase shifts and backscattering amplitudes determined experimentally for materials of known crystal structure. The Pt-Pt

(1) Lamb, H. H.; Krause, T. R.; Gates, B. C. J. Chem. Soc., Chem. Commun. 1986, 821 .

(2) Maloney, S. D.; van Zon, F. B. M.; Kelley, M. J.; Koningsberger, D. C.; Gates, B. C. Catal. Lett, 1990, 5, 161.

(3) Puga, J.; Patrini, R.: Sanchez, K. M.; Gates, B. C. Inorg. Chem. 1991, 30,2479

(4) van Zon, F. B. M.; Maloney, S. D.; Gates, B. C.; Koningsberger, D. C. To be published.

(5) Longoni, G.: Chini, P. J. Am. Chem. Soc. 1976, 98, 7225

(6) Bhaduri, S.; Sharma, K. R. J. Chem. Soc., Dalton Trans. 1984, 2309.

(7) Bhaduri, S.; Sharma, K. R. J. Chem. Soc., Dalton Trans. 1984, 2315.

(8) Ichikawa, M. Chem. Lett. 1976, 335

(9) Handy, B. E.; Dumesic, J. A.; Langer, S. H. J. Catal. 1990, 126, 73. 


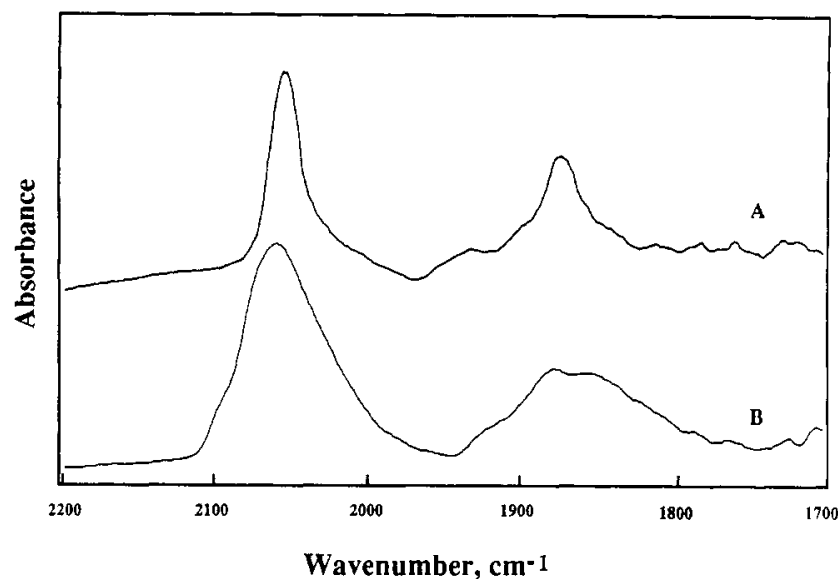

Figure 1. IR spectra of platinum carbonyl dianions prepared by a surface-mediated reductive carbonylation synthesis: A, species extracted from the $\mathrm{MgO}$ surface by ion exchange with [PPN][Cl] in THF; $\mathrm{B}$, $\mathrm{MgO}$-supported species.

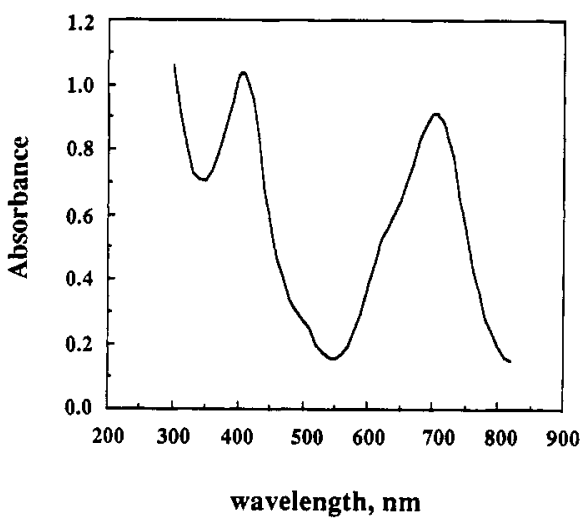

Figure 2. UV-visible spectrum of platinum carbonyl dianions extracted from the $\mathrm{MgO}$ surface by ion exchange with [PPN][Cl] in THF.

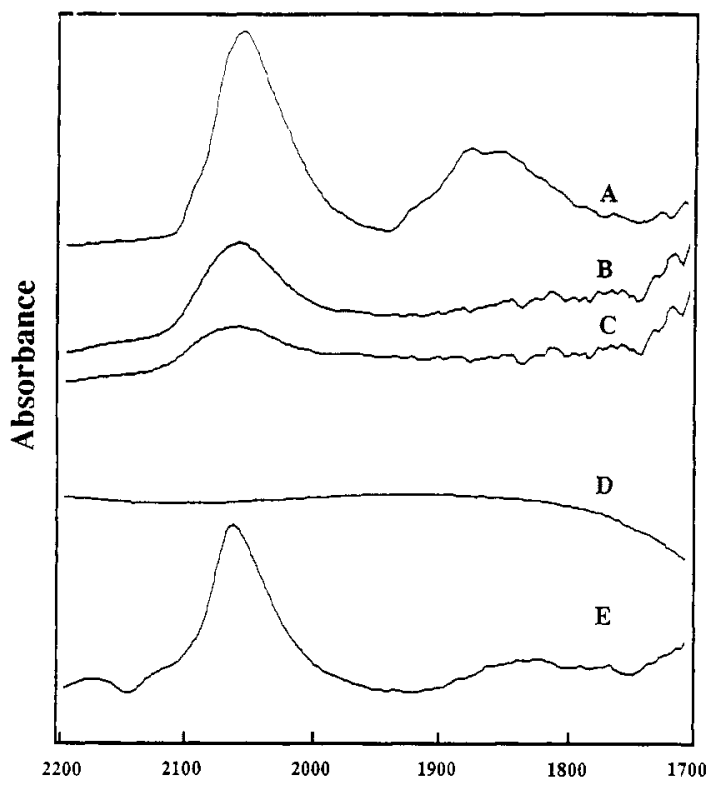

Wavenumber, $\mathrm{cm}^{-1}$

Figure 3. IR spectra of the $\mathrm{MgO}$-supported species formed from $\mathrm{Na}_{2}$ $\mathrm{PtCl}_{6} \cdot 6 \mathrm{H}_{2} \mathrm{O}$ by a surface-mediated reductive carbonylation synthesis: A, freshly prepared sample; B, sample after $10 \mathrm{~min}$ at $75^{\circ} \mathrm{C}$ under vacuum (0.01-0.001 Torr); C, sample after $30 \mathrm{~min}$ at $75^{\circ} \mathrm{C}$ under vacuum; $\mathrm{D}$, sample after $30 \mathrm{~min}$ at $100^{\circ} \mathrm{C}$ under vacuum; E, sample exposed to 1 atm of $\mathrm{CO}$.

and $\mathrm{Pt}-\mathrm{O}_{\text {support }}$ contributions were analyzed with phase shifts and backscattering amplitudes obtained from EXAFS data for Pt foil

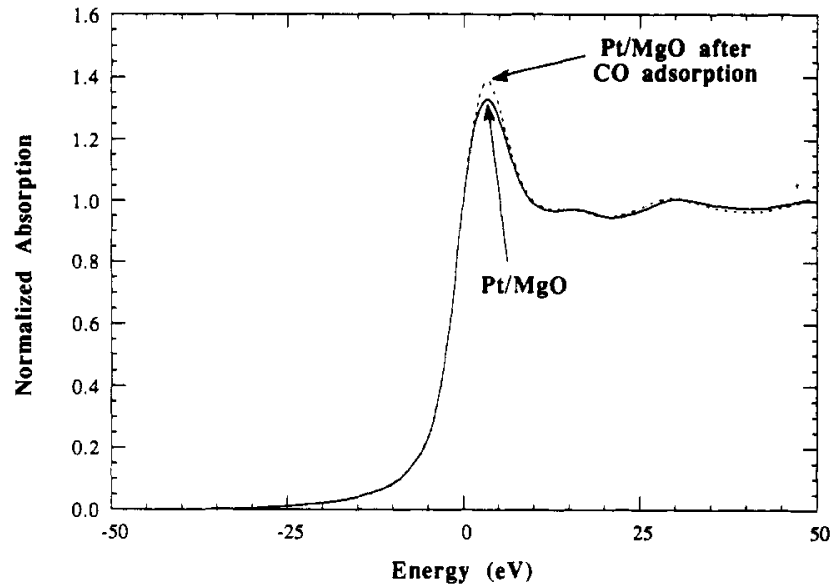

Figure 4. Structure of $\mathrm{PtL}_{\mathrm{III}}$ absorption edge characterizing the supported $\mathrm{Pt}$ sample formed from the decarbonylation of the $\mathrm{Pt}$ carbonyl clusters on $\mathrm{MgO}$ at $120^{\circ} \mathrm{C}$ : under vacuum (solid line); following $\mathrm{CO}$ treatment at $25^{\circ} \mathrm{C}$ and $1 \mathrm{~atm}$ (dashed line).

Table II. Structural Parameters Characterizing Reference Materials Used in the EXAFS Analysis ${ }^{a}$

\begin{tabular}{|c|c|c|c|c|c|c|}
\hline \multirow[b]{2}{*}{ sample } & \multicolumn{3}{|c|}{$\begin{array}{l}\text { crystallographic } \\
\text { data }^{b}\end{array}$} & \multicolumn{3}{|c|}{ Fourier transform data } \\
\hline & shell & $N$ & $\overline{R, \AA}$ & $\overline{\Delta k, \AA^{-1}}$ & $\Delta r, \AA$ & $n$ \\
\hline $\begin{array}{l}\mathrm{Pt} \text { foil } \\
\mathrm{Na}_{2} \mathrm{Pt}(\mathrm{OH})_{6} \\
\mathrm{Ir}-\mathrm{Al} \text { alloy } \\
\mathrm{Ir}_{4}(\mathrm{CO})_{12}\end{array}$ & $\begin{array}{l}\mathrm{Pt}-\mathrm{Pt}^{b} \\
\mathrm{Pt}-\mathrm{O}^{c} \\
\mathrm{I}-\mathrm{Al}^{d} \\
\mathrm{I} r-\mathrm{Ir} \\
\mathrm{I}-\mathrm{C}^{e} \\
\mathrm{I} \mathbf{r}-\mathrm{O}^{* e}\end{array}$ & $\begin{array}{r}12 \\
6 \\
8 \\
3 \\
3 \\
3\end{array}$ & $\begin{array}{l}2.77 \\
2.05 \\
2.58 \\
2.69 \\
1.87 \\
3.01\end{array}$ & $\begin{array}{l}1.9-19.8 \\
1.4-17.7 \\
3.0-12.3\end{array}$ & $\begin{array}{l}1.9-3.0 \\
0.5-2.0 \\
0.9-2.5 \\
\\
1.1-2.0 \\
2.0-3.3\end{array}$ & $\begin{array}{l}3 \\
3 \\
3\end{array}$ \\
\hline
\end{tabular}

${ }^{a}$ Notation: $N$, coordination number for absorber-backscatterer pair; $R$, radial distance from crystal structure data; $\Delta k$ limits used for forward Fourier transformation ( $k$ is the wave vector); $\Delta r$, limits used for shell isolation ( $r$ is distance); $n$, power of $k$ used for Fourier transformation. ${ }^{b}$ Crystal structure data from: Wyckoff, R. W. G. Crystal Structures, 2nd ed.; Wiley: New York, 1963; Vol. I, p 10. ' Crystal structure data from: Trömel, M.; Lupprich, E. Z. Anorg. Chem. 1975, 414,60. ${ }^{d}$ Crystal structure data from: Esslinger, P.; Schubert, K. $Z$. Metallkd. 1957, 48, 126. After subtraction of the Ir-Ir contribution, $N=3, R=2.99 \AA$, the Debye-Waller factor $\Delta \sigma^{2}=0.0033 \AA^{2}$, and $E_{0}$ $=-3.5 \mathrm{eV}$. ${ }^{e}$ Crystal structure data from: Churchill, M. R.; Hutchinson, J. P. Inorg. Chem. 1978, 17, 3528. After subtraction of the Ir-Ir contribution, $N=6, R=2.69 \AA, \Delta \sigma^{2}=-0.001 \AA^{2}$, and $E_{0}=2.5 \mathrm{eV}$.

and $\mathrm{Na}_{2} \mathrm{Pt}(\mathrm{OH})_{6}$, respectively. The $\mathrm{Pt}-\mathrm{C}$ and $\mathrm{Pt}-\mathrm{O}^{*}$ interactions (where $\mathrm{O}^{*}$ denotes the oxygen of a carbonyl ligand) were analyzed with phase shifts and backscattering amplitudes obtained from EXAFS data for crystalline $\left[\mathrm{Ir}_{4}(\mathrm{CO})_{12}\right]$ (which has only terminal $\mathrm{CO}$ ligands) mixed with $\mathrm{SiO}_{2}$. $\left[\mathrm{Ir}_{4}(\mathrm{CO})_{12}\right]$ was chosen because the multiple-scattering effect in the $\mathrm{Pt}-\mathrm{O}^{*}$ shell is significant (as a consequence of the linear $\mathrm{Ir}-\mathrm{C}-\mathrm{O}^{*}$ arrangement), and it was necessary to use a reference that exhibits multiple scattering. ${ }^{10}$ The transferability of the phase shift and backscattering amplitudes for $\mathrm{Pt}$ and Ir has been justified both experimentally ${ }^{12,13}$ and theoretically. ${ }^{14}$ An IrAl alloy was used as a reference for the $\mathrm{Pt}-\mathrm{Mg}$ absorber-scatterer pair because $\mathrm{Al}$ and $\mathrm{Mg}$ are nearby in the periodic table. Details of the preparation of the reference files are given elsewhere. ${ }^{11}$ EXAFS parameters characteristic of the reference materials are summarized in Table II.

EXAFS Data and Preliminary Analysis. EXAFS data from two scans were averaged for each sample. The normalized EXAFS functions were obtained from the averaged X-ray absorption spectra by a cubic spline background subtraction and normalized

(10) Teo, B.-K. J. Am. Chem. Soc. 1981, 103, 3990.

(11) van Zon, F. B. M. Ph.D. Dissertation, Eindhoven University of Technology, Eindhoven, The Netherlands, 1988.

(12) Duivenvoorden, F. B. M.; Koningsberger, D. C.; Uh, Y. S.; Gates, B. C. J. Am. Chem. Soc. 1986, 108, 6254.

(13) Lengler, B. J. Phys. (Paris) 1986, 47, C8-75.

(14) Teo, B.-K.; Lee, P. A. J. Am. Chem. Soc. 1979, I01, 2815. 
by division by the edge height. ${ }^{11}$ The noise amplitude determined from the EXAFS averaging routine was about 0.001 , and the signal amplitude at a value of $k$ ( $k$ is the wave vector) of $4 \AA^{-1}$ was about 0.04 . These values give an estimated signal to noise ratio of $40 / 1$. The $k^{3}$-weighted $\mathrm{Pt}-\mathrm{Pt}$ phase- and amplitudecorrected Fourier transforms of the EXAFS functions in $r$ space show that the amplitude of the major peak increased as a result of adsorption of $\mathrm{CO}$, which implies that the $\mathrm{Pt}-\mathrm{Pt}$ coordination number of the supported catalyst increased after $\mathrm{CO}$ adsorption. This inference is in need of further justification, however, because the major peak characteristic of the decarbonylated supported $\mathrm{Pt}$ sample contains only the Pt-Pt contribution, whereas both $\mathrm{Pt}-\mathrm{Pt}$ and $\mathrm{Pt}-\mathrm{O}^{*}$ contributions characterize the sample after $\mathrm{CO}$ adsorption.

Detailed EXAFS Analysis for Decarbonylated $\left[\mathrm{Pt}_{15}(\mathrm{CO})_{30}\right]^{2-}$ on MgO. A normal $k^{2}$-weighted Fourier transformation without correction was performed on the EXAFS data over the useful range $\left(3.51<k<13.84 \AA^{-1}\right)$. The major contributions were isolated by inverse Fourier transformation in the range $0.924<$ $r<3.409 \AA$. With the Koningsberger difference-file technique, ${ }^{15,16}$ the Pt-Pt contribution, the largest component in the EXAFS spectrum, was estimated by calculating an EXAFS function that agreed as closely as possible with the experimental results in the high- $k$ range $\left(7.5<k<13.5 \AA^{-1}\right)$; the metal-support contributions in this region are small. An EXAFS function calculated with the first-guess parameters was then subtracted from the data. The residual spectrum was expected to represent the metal-support interactions, including $\mathrm{Pt}-\mathrm{O}_{\text {support }}$ and $\mathrm{Pt}-\mathrm{Mg}$ interactions. The difference file was estimated with two $\mathrm{Pt}-\mathrm{O}$ contributions (a shorter ${ }^{17-20}$ and a longer one ${ }^{16,21-23}$ ) first. As a first approximation, only four free parameters were estimated $\left(\Delta \sigma^{2}\right.$, the Debye-Waller factor, and $\Delta E_{0}$, the inner potential correction, were set equal to $0)$ to shorten the time for parameter estimation.

The first-guess $\mathrm{Pt}-\mathrm{Pt}$ and $\mathrm{Pt}-\mathrm{O}_{\text {support }}$ contributions were then added and compared with the raw data in $r$ space, and the fit was still not satisfactory. Then the $\mathrm{Pt}-\mathrm{O}_{\text {support }}$ contribution was subtracted from the data, and better parameters for the Pt-Pt contribution were estimated. The improved fit for the Pt-Pt contribution was subtracted from the data, and more accurate parameters for the contributions of the metal-support interface were determined by fitting the metal-support contributions to the residual spectrum with eight adjustable parameters; the initial guesses for parameter estimation were determined by adjusting the coordination parameters to give the best agreement with the residual spectrum, both in $k$ space and in $r$ space. This process was repeated, but even after many iterations, the fit was not good in the region $1.3<r<2.0 \AA$. It was thus inferred that another contribution, $\mathrm{Pt}-\mathrm{Mg}$, had to be accounted for. A difference file was calculated by subtracting the best estimated $\mathrm{Pt}-\mathrm{Pt}+\mathrm{Pt}-$ $\mathrm{O}_{\text {support }}$ contribution from the experimental EXAFS function. The $\mathrm{Pt}-\mathrm{Mg}$ contribution was calculated by fitting the difference file with four adjustable parameters.

The Pt-Pt, $\mathrm{Pt}-\mathrm{Mg}$, and two $\mathrm{Pt}-\mathrm{O}_{\text {support }}$ contributions were then added, representing the overall fit of the data. To show the goodness of fit for both the high- $Z(\mathrm{Pt})$ and low- $Z(\mathrm{Mg}, \mathrm{O})$ contributions, the raw data are compared with the fit, both in $k$

(15) Kirlin, P. S.; van Zon, F. B. M.; Koningsberger, D. C.; Gates, B. C. J. Phys. Chem. 1990, 94, 8439.

(16) van Zon, J. B. A. D.; Koningsberger, D. C.; van't Blik, H. F. J.; Sayers, D. E. J. Chem. Phys. 1985, 82, 5742.

(17) Emrich, R. J.; Mansour, A. N.; Sayers, D. E.; McMillan, S. T.; Katzer, J. R. J. Phys. Chem. 1985, 89, 4261.

(18) Lytle, F. W.; Greegor, R. B.; Marques, E. C.; Via, G. H.; Sinfelt, J. H. J. Catal. 1985, 95,546 .

(19) Via, G. H.; Sinfelt, J. H.; Lytle, F. W. J. Chem. Phys. 1979, 71,690

(20) Lagarde, P.; Murata, T.; Vlaic, G.; Freund, E.; Dexpert, H.; Bournonville, J. P. J. Catal. 1983, 84, 33

(21) Koningsberger, D. C.; van Zon, J. B. A. D.; van't Blik, H. F. J.; Visser G. J.; Prins, R.; Mansour, A. N.; Sayers, D. E.; Short, D. R.; Katzer, J. R. J. Phys. Chem. 1985, 89, 4075 .

(22) Koningsberger, D. C.; Martens, J. H. A.; Prins, R.; Short, D. R. Sayers, D. E. J. Phys. Chem. 1986, 90, 3047.

(23) Martens, J. H. Ph.D. Dissertation, Eindhoven University of Tech. nology, Eindhoven, The Netherlands, 1988.
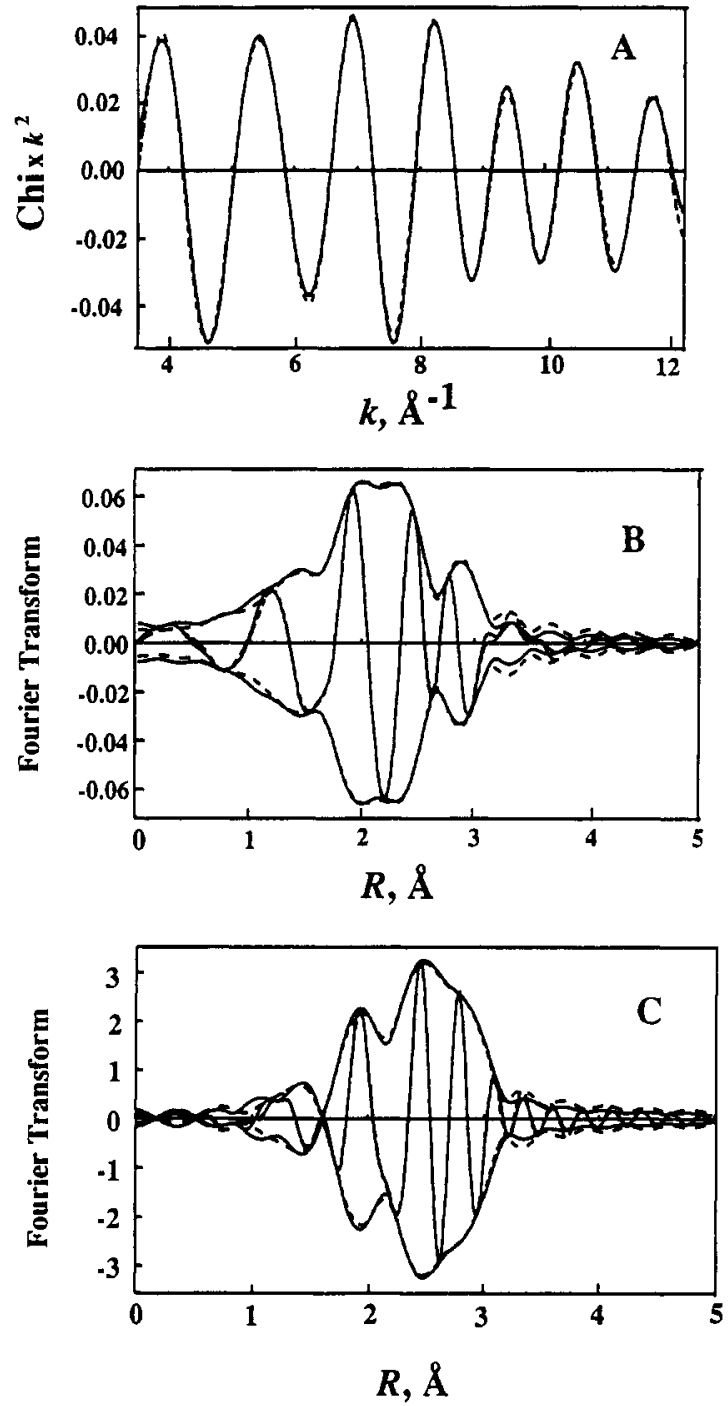

Figure 5. Results of EXAFS analysis obtained with the best calculated courdination parameters for the supported $\mathrm{Pt}$ sample prepared from the decarbonylation of the $\mathrm{Pt}$ carbonyl clusters on $\mathrm{MgO}$ at $120^{\circ} \mathrm{C}$ under vacuum: A, EXAFS data (solid line) and sum of the calculated $\mathrm{Pt}-\mathrm{Pt}$ $+\mathrm{Pt}-\mathrm{Mg}+\mathrm{Pt}-\mathrm{O}_{\text {support }}$ contributions (dashed line); B, imaginary part and magnitude of Fourier transform ( $k^{3}$-weighted, $\left.\Delta k=3.5-12.2 \AA^{-1}\right)$ of EXAFS data (solid line) and sum of the calculated $\mathrm{Pt}-\mathrm{Pt}+\mathrm{Pt}-\mathrm{Mg}+$ $\mathrm{Pt}-\mathrm{O}_{\text {support }}\left(\mathrm{Pt}-\mathrm{O}_{1}+\mathrm{Pt}-\mathrm{O}_{\mathrm{s}}\right)$ contributions (dashed line); $\mathrm{C}$, imaginary part and magnitude of Fourier transform ( $k^{1}$-weighted, $\Delta k=3.5-12.2$ $\AA^{-1}$ ) of EXAFS data (solid line) and sum of the calculated Pt-Pt + $\mathrm{Pt}-\mathrm{Mg}+\mathrm{Pt}-\mathrm{O}_{\text {support }}$ contributions (dashed line).

Table III. EXAFS Results Characterizing the Surface Species Formed after Decarbonylation of $\left[\mathrm{Pt}_{15}(\mathrm{CO})_{30}\right]^{2-}$ on $\mathrm{MgO}_{400}{ }^{a, b}$

\begin{tabular}{cccccc}
\hline shell & $N$ & $R, \AA$ & \multicolumn{1}{c}{$\Delta \sigma^{2}, \AA^{2}$} & $\Delta E_{0}, \mathrm{eV}$ & EXAFS ref \\
\hline $\mathrm{Pt}-\mathrm{Pt}$ & 3.7 & 2.76 & 0.0033 & -0.87 & $\mathrm{Pt}-\mathrm{Pt}$ \\
$\mathrm{Pt}_{-} \mathrm{O}_{\text {support }}$ & & & & & \\
$\mathrm{Pt}_{1} \mathrm{O}_{1}$ & 1.9 & 2.68 & 0.00512 & 0.57 & $\mathrm{Pt}-\mathrm{O}$ \\
$\mathrm{Pt}-\mathrm{O}_{\mathrm{s}}$ & 0.9 & 2.20 & 0.00300 & -3.0 & \\
$\mathrm{Pt}-\mathrm{Mg}_{\mathrm{g}}$ & 0.27 & 1.74 & 0.0010 & -4.0 & $\mathrm{Ir}-\mathrm{Al}$ \\
\hline
\end{tabular}

${ }^{a}$ Notation: $N$, coordination number for absorber-backscatter pair; $R$, radial distance; $\Delta \sigma^{2}$, Debye-Waller factor, difference with respect to reference compound; $\Delta E_{0}$, inner potential correction (correction on the edge position); see ref 24 for details. ' ${ }^{b}$ Estimated precision: $N$, $\pm 15 \%$ (Pt-Mg, $\pm 30 \%) ; R, \pm 1 \%(\mathrm{Pt}-\mathrm{Mg}, \pm 2 \%) ; \Delta \sigma^{2}, \pm 30 \% ; \Delta E_{0}$, $\pm 10 \%$.

space (with $k^{2}$ weighting) and in $r$ space (with both $k^{1}$ and $k^{3}$ weighting) (Figure 5). The agreement is good. The structural parameters are shown in Table III. The number of parameters used to fit the data in this main-shell analysis is 16; the statistically justified number is approximately 17 , estimated from the Nyquist theorem, ${ }^{24} n=(2(\Delta k) \Delta r / \pi)+1$, where $\Delta k$ and $\Delta r$, respectively, 
Table IV. EXAFS Results Characterizing the Surface Species Formed after $\mathrm{CO}$ Treatment of Pt Supported on $\mathrm{MgO}_{400}{ }^{a, b}$

\begin{tabular}{cccccc}
\hline shell & $N$ & $R, \AA$ & $\Delta \sigma^{2}, \AA^{2}$ & $\Delta E_{0}, \mathrm{eV}$ & EXAFS ref \\
\hline $\mathrm{Pt}^{\mathrm{Pt}}$ & 6.00 & 2.78 & 0.0041 & -0.52 & $\mathrm{Pt}-\mathrm{Pt}$ \\
$\mathrm{Pt}-\mathrm{O}_{\text {support }}$ & & & & & \\
$\mathrm{Pt}^{-\mathrm{O}_{1}}$ & 0.58 & 2.78 & 0.0078 & 4.16 & $\mathrm{Pt}-\mathrm{O}$ \\
$\mathrm{Pt}-\mathrm{O}_{\mathrm{s}}$ & 0.89 & 2.19 & 0.0047 & -4.86 & \\
$\mathrm{Pt}-\mathrm{CO}$ & & & & & \\
$\mathrm{Pt}-\mathrm{C}$ & 0.82 & 1.86 & 0.0034 & 0.71 & $\mathrm{Ir}-\mathrm{C}$ \\
$\mathrm{Pt}-\mathrm{O}^{*}$ & 0.77 & 2.99 & 0.0032 & -3.72 & $\mathrm{Ir}-\mathrm{O}^{*}$ \\
\hline
\end{tabular}

${ }^{a}$ Notation as in Table III. ${ }^{b}$ Estimated precision: $N, \pm 15 \%\left(\mathrm{Pt}-\mathrm{O}^{*}\right.$, $\pm 30 \%) ; R, \pm 1 \%\left(\mathrm{Pt}-\mathrm{O}^{*}, \mathrm{Pt}-\mathrm{C}, \mathrm{Pt}-\mathrm{O}_{1}\right.$, and $\left.\mathrm{Pt}-\mathrm{O}_{s}, \pm 2 \%\right) ; \Delta \sigma^{2}, \pm 30 \%$; $\Delta E_{0}, \pm 10 \%$.

are the $k$ and $r$ ranges used in the forward and inverse Fourier transforms $\left(\Delta k=10.3 \AA^{-1} ; \Delta r=2.483 \AA\right.$ ).

Detailed Analysis for the Supported Pt Clusters after Recarbonylation. The data characterizing the sample after $\mathrm{CO}$ treatment were analyzed similarly. The EXAFS data were Fourier-transformed over the useful range $\left(2.98<k<14.83 \AA^{-1}\right)$ with $k^{2}$ weighting and no correction. The major contributions were isolated by inverse Fourier transformation in the range 0.482 $<r<3.250 \AA$. As before, the $\mathrm{Pt}-\mathrm{Pt}$ contribution, the largest component in the EXAFS spectrum, was estimated first. However, since the $\mathrm{Pt}-\mathrm{O}^{*}$ contribution was strongly coupled with the $\mathrm{Pt}-\mathrm{Pt}$ contribution, these two contributions had to be analyzed simultaneously. The structural parameters were estimated by fitting the data in the high- $k$ range $\left(7.5<k<14.5 \AA^{-1}\right)$. The multiple scattering associated with $\mathrm{Pt}-\mathrm{C}-\mathrm{O}^{*}$ groups was found to be significant in this range, with metal-support interface and $\mathrm{Pt}-\mathrm{C}$ contributions being insignificant. Further analysis following the subtraction of the calculated $\mathrm{Pt}-\mathrm{Pt}$ and $\mathrm{Pt}-\mathrm{O}^{*}$ contributions from the raw data led to characterization of the metal-support and the $\mathrm{Pt}-\mathrm{C}$ contributions. The structural parameters characterizing these contributions were determined by fitting the residual spectrum with 12 parameters. The initial guesses for parameter estimation were again obtained by adjusting the coordination parameters to give the best fit of the residual spectrum in $r$ space. The calculated $\mathrm{Pt}-\mathrm{C}$ and $\mathrm{Pt}-\mathrm{O}_{\text {support }}$ contributions were subtracted from the raw data. Better parameters for the $\mathrm{Pt}-\mathrm{Pt}$ and $\mathrm{Pt}-\mathrm{O}^{*}$ contributions were then estimated by fitting the residual spectrum. The refinement through this iteration was continued until good overall agreement was obtained. The final results are summarized in Table IV, and the comparisons of the data and the fit, both in $k$ space and in $r$ space, are shown in Figure 6. The number of parameters used to fit the data in this first-shell analysis is 20; the statistically justified number, calculated as above, is approximately 22 .

\section{Discussion}

Synthesis of $\left[\mathrm{Pt}_{15}(\mathrm{CO})_{30}\right]^{2-}$ on the $\mathrm{MgO}$ Surface. The results are consistent with the conclusion that $\mathrm{PtCl}_{6}{ }^{2-}$ on the $\mathrm{MgO}$ surface was converted into $\left[\mathrm{Pt}_{15}(\mathrm{CO})_{30}\right]^{2-}$ in the presence of $\mathrm{CO}$. The extraction of this anion into solution confirms that it was present on the surface, and the color and infrared spectra of the solid are consistent with the inference that this anion was the predominant organometallic species on the surface. The infrared spectrum of the surface species $\left(2059 \mathrm{~s}, 1877 \mathrm{~s}, 1853 \mathrm{~s} \mathrm{~cm}^{-1}\right)$ is indistinguishable from that of $\left[\mathrm{Pt}_{15}(\mathrm{CO})_{30}\right]^{2-}$ in THF solution, except for the additional peak at $1853 \mathrm{~cm}^{-1}$. This peak is characteristic of bridging $\mathrm{CO}$ ligands, with the shift to lower energy suggested to be a consequence of interactions of such ligands with Lewis acid sites $\left(\mathrm{Mg}^{2+}\right)$ on the $\mathrm{MgO}$ surface. Similar results have been reported by Handy et al., ${ }^{9}$ who adsorbed the PPN salt of $\left[\mathrm{Pt}_{15^{*}}\right.$ $\left.(\mathrm{CO})_{30}\right]^{2-}$ onto $\gamma-\mathrm{Al}_{2} \mathrm{O}_{3}$; they observed infrared peaks at 2058 and $1862 \mathrm{~cm}^{-1}$.

The synthesis of $\left[\mathrm{Pt}_{15}(\mathrm{CO})_{30}\right]^{2-}$ on the basic $\mathrm{MgO}$ surface is consistent both with the chemistry of platinum carbonyls in basic solutions, reported by Longoni and Chini, ${ }^{5}$ and with the surface

(24) Koningsberger, D. C.; Prins, R. X-ray Absorption: Principles, Ap. plications, Techniques of EXAFS, SEXAFS and XANES; Wiley: New York, 1988; p 395
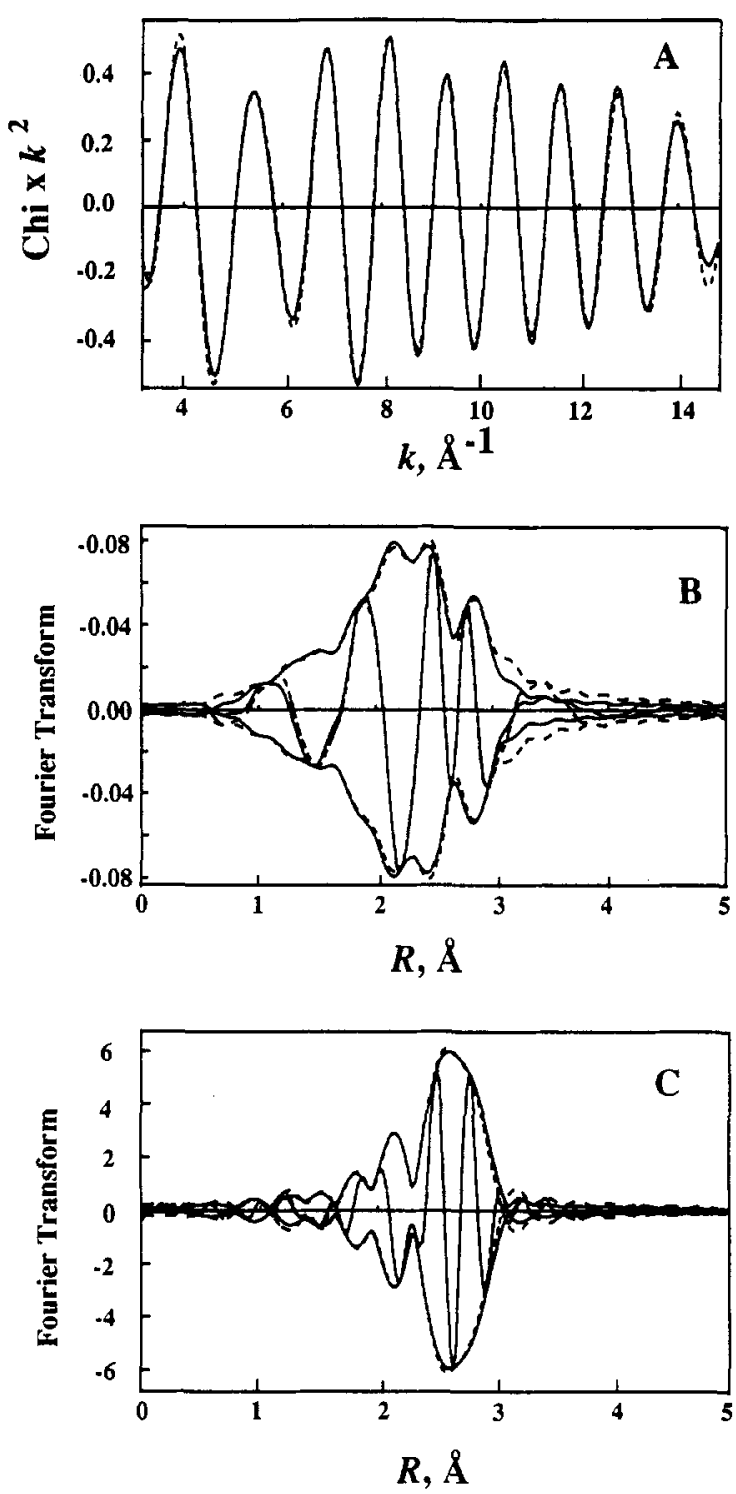

Figure 6. Results of EXAFS analysis obtained with the best calculated coordination parameters for the supported $\mathrm{Pt}$ sample prepared from the decarbonylation of the $\mathrm{Pt}$ carbonyl clusters on $\mathrm{MgO}$ at $120^{\circ} \mathrm{C}$ under vacuum, followed by $\mathrm{CO}$ treatment at $25^{\circ} \mathrm{C}$ and $1 \mathrm{~atm}$ : A, EXAFS data (solid line) and sum of the calculated $\mathrm{Pt}-\mathrm{Pt}+\mathrm{Pt}-\mathrm{Mg}+\mathrm{Pt}-\mathrm{O}_{\text {support }}$ contributions (dashed line); B, imaginary part and magnitude of Fourier transform ( $k^{3}$-weighted, $\left.\Delta k=3.00-14.8 \AA^{-1}\right)$ of EXAFS data (solid line) and sum of the calculated $\mathrm{Pt}-\mathrm{Pt}+\mathrm{Pt}-\mathrm{Mg}+\mathrm{Pt}-\mathrm{O}_{\text {support }}\left(\mathrm{Pt}-\mathrm{O}_{1}+\mathrm{Pt}-\mathrm{O}_{\mathrm{s}}\right)$ contributions (dashed line); $\mathrm{C}$, imaginary part and magnitude of Fourier transform ( $k^{1}$-weighted, $\Delta k=3.00-14.8 \AA^{-1}$ ) of EXAFS data (solid line) and sum of the calculated $\mathrm{Pt}-\mathrm{Pt}+\mathrm{Pt}-\mathrm{Mg}+\mathrm{Pt}-\mathrm{O}_{\text {support }}$ contributions (dashed line).

chemistry reported by Puga et al., ${ }^{3}$ who formed $\left[\mathrm{Pt}_{9}(\mathrm{CO})_{18}\right]^{2-}$ and, separately, $\left[\mathrm{Pt}_{12}(\mathrm{CO})_{24}\right]^{2-}$ on $\mathrm{MgO}$. The surface-mediated synthesis reported here is simple and gives $\left[\mathrm{Pt}_{15}(\mathrm{CO})_{30}\right]^{2-}$ in high yield ( $>73 \%$, based on a single extraction with [PPN][CI]). The method is evidently more effective than that reported by Puga et al., ${ }^{3}$ as indicated by the more precise agreement in this work than in Puga's of the spectrum of the extracted platinum cluster anion with that of the pure anion in solution. The method used here is almost the same as Puga's; the improvement is attributed to the minimization of the surface contamination by traces of air in this work; the solvent (methanol or hexane) evidently protected the platinum complex by providing resistance to mass transfer of oxygen. The method reported here also gives higher yields of $\left[\mathrm{Pt}_{9}(\mathrm{CO})_{18}\right]^{2-}$ than Puga's method.

Decarbonylation of $\left[\mathrm{Pt}_{15}(\mathrm{CO})_{30}\right]^{2-}$ Supported on $\mathrm{MgO}$. The decarbonylation of $\left[\mathrm{Pt}_{15}(\mathrm{CO})_{30}\right]^{2-}$ on $\mathrm{MgO}$ was carried out under vacuum by gradually increasing the temperature. Both terminal 
and bridging absorption bands decreased in intensity as the temperature was increased. The peaks at 1877 and $1853 \mathrm{~cm}^{-1}$ (indicating bridging $\mathrm{CO}$ ) decreased in intensity faster than the peak at $2059 \mathrm{~cm}^{-1}$ (indicating terminal $\mathrm{CO}$ ). These results suggest that the bridging $\mathrm{CO}$ ligands are more labile than the terminal ligands and are consistent with the work of Handy et al. ${ }^{9}$ However, in Handy's work, both the terminal and bridging bands shifted to lower energy as the degree of decarbonylation increased; such a result was not observed in this work. The reasons for the difference may be related to the difference in the decarbonylation environment; our sample was evacuated, but Handy's was treated in $\mathrm{He}$ and presumably contained residual $\mathrm{CO}$, which may have readsorbed on the metal, with the amount decreasing with increasing temperature. The decrease of $\mathrm{CO}$ coverage leads to diminished dipole-dipole coupling between adjacent $\mathrm{CO}$ molecules and a lower energy shift of the $\mathrm{CO}$ absorption bands. ${ }^{25,26}$

To investigate the structure of the clusters resulting from the decarbonylation, the sample was characterized by EXAFS spectroscopy. The $\mathrm{Pt}-\mathrm{Pt}$ coordination number characteristic of the sample prepared by decarbonylation of $\left[\mathrm{Pt}_{15}(\mathrm{CO})_{30}\right]^{2-}$ on $\mathrm{MgO}$ (Table III), 3.7, is nearly the same as the crystallographically determined $\mathrm{Pt}-\mathrm{Pt}$ coordination number ${ }^{5}$ of $\left[\mathrm{Pt}_{15}(\mathrm{CO})_{30}\right]^{2-}(3.6)$. This result suggests that the structure of the Pt cluster frame after decarbonylation resembles that of the trigonal prism of $\left[\mathrm{Pt}_{15^{-}}\right.$ $\left.(\mathrm{CO})_{30}\right]^{2-}$. This suggestion is consistent with infrared spectra and the EXAFS results characterizing the metal-support interface (Table III) as follows: There was no significant band shift or peak splitting observed in the infrared spectra recorded during the decarbonylation of $\left[\mathrm{Pt}_{15}(\mathrm{CO})_{30}\right]^{2-}$ on $\mathrm{MgO}$, which implies that no detectable $\mathrm{Pt}$ carbonyl clusters formed as intermediates. The only possible structure of a $\mathrm{Pt}_{15}$ cluster with a $\mathrm{Pt}-\mathrm{Pt}$ coordination number of 3.7 is rodlike. The coordination number characterizing the metal-support interface, namely, $2.8\left(\mathrm{Pt}-\mathrm{O}_{\mathrm{s}}+\mathrm{Pt}-\mathrm{O}_{1}\right)$ (where $\mathrm{s}$ refers to the short and 1 to the long $\mathrm{Pt}-\mathrm{O}$ distance), is close to 2.67 , which is the value expected for a trigonal prism of Pt atoms on the (100) face of $\mathrm{MgO}$, which is the most stable (and predominant) face of $\mathrm{MgO} .{ }^{27}$ Other plausible structures, such as a square prism, have metal-support coordination numbers less than $\mathbf{2 . 0}$ and are ruled out. In summary, all the data are consistent with a trigonal prism, and we regard this structure as an appropriate model of the decarbonylated Pt clusters. The model is simplified, as there may be a variety of structures rather than just one, and as the $\mathrm{MgO}$ support surface is inherently nonuniform.

Recarbonylation of the Supported Pt Clusters. After the $\mathrm{MgO}$-supported $\left[\mathrm{Pt}_{15}(\mathrm{CO})_{30}\right]^{2-}$ had been decarbonylated and cooled to room temperature, it was exposed to flowing $\mathrm{CO}$ at 1 atm in an attempt to regenerate the $\mathrm{Pt}$ carbonyl clusters. A terminal $\mathrm{CO}$ absorption band with about $70 \%$ of the intensity of that characterizing the original $\left[\mathrm{Pt}_{15}(\mathrm{CO})_{30}\right]^{2-}$ appeared at 2064 $\mathrm{cm}^{-1}$, but the bridging $\mathrm{CO}$ peaks did not reappear. These results are consistent with those of Handy et al., ${ }^{9}$ who observed that only a terminal CO peak at $2072 \mathrm{~cm}^{-1}$ reappeared upon recarbonylation of the sample prepared from the deposited salt of $\left[\mathrm{Pt}_{15}(\mathrm{CO})_{30}\right]^{2-}$. The results show that the original $\mathrm{Pt}$ carbonyl clusters were not regenerated after $\mathrm{CO}$ readsorption.

After $\mathrm{CO}$ treatment of the decarbonylated sample, the $\mathrm{Pt}-\mathrm{Pt}$ first-shell coordination number increased from 3.7 to 6.0 , and the $\mathrm{Pt}-\mathrm{O}\left(\mathrm{Pt}-\mathrm{O}_{\mathrm{s}}+\mathrm{Pt}-\mathrm{O}_{1}\right)$ coordination number decreased from 2.8 to 1.4 (Tables III and IV), indicating the increased size of the Pt clusters. A further characterization of the structure of these Pt clusters is provided by the higher metal-metal shell contributions. According to the report of van Zon et al., ${ }^{4}$ small supported Ir clusters assumed to have a face centered cubic structure on a (100) basal plane of $\mathrm{MgO}$ showed a high amplitude of the second metal-metal shell, consistent with nearly hemispherical clusters. The increase in the intensity of the Pt-Pt higher-shell contribution observed in this work as a result of recarbonylation (Figure 6)

(25) Primet, M.; Basset, J.-M.; Mathieu, M. V.; Prettre, M. J. Catal. 1973 29,213

(26) Primet, M. J. Catal. 1984, 88, 273

(27) Henrich, V. C. Rep. Prog. Phys. 1985, 48, 1481 indicates a change in the morphology of the clusters from that resembling trigonal prisms to that resembling hemispheres. The average clusters changed from about $1.5 \mathrm{~nm}$ long trigonal prisms to hemispheres with a diameter of about $1.0 \mathrm{~nm}$. The average $\mathrm{Pt}-\mathrm{Pt}$ bond distance increased from 2.76 to $2.78 \AA$, and the Debye-Waller factor increased slightly (indicating a small increase in the dispersion of Pt-Pt distances). The increases in the average $\mathrm{Pt}-\mathrm{Pt}$ distance and in the Debye-Waller factor are small (within experimental error) and are not conclusive evidence, but they are consistent with the growth of the Pt clusters upon CO adsorption. Several groups have observed lengthening of the metal-metal bond distance with the growth of supported metal clusters. ${ }^{28-30}$

The intensity of the threshold resonance of the $\mathrm{L}_{\mathrm{III}}$ absorption edge (white line) is related to the transition probabilities of exciting inner-core $2 p$ electrons into vacant $d$ valance levels. The lower the electron density of the metal, the greater the number of vacancies in the valence level and, hence, the higher the probability of the transition. ${ }^{31}$ The effect of $\mathrm{CO}$ adsorption on the d-hole density of $\mathrm{Pt}$ can thus be inferred from the white-line intensity. However, a correction of white-line intensities to account for the influence of the metal cluster size is needed.

Hartree-Fock-Slater LCAO calculations show a decrease of the d-hole density with increasing size of ionized clusters. ${ }^{32}$ The result is consistent with XANES experiments; the white-line intensity of supported metal clusters decreases with increasing cluster size, and the XANES spectrum is computed by considering scattering of the electron in the field of the ionized cluster. ${ }^{33}$

From the EXAFS results, it was at first expected that the white-line intensity would decrease after $\mathrm{CO}$ adsorption because of the growth of the Pt clusters. However, the reverse was observed. The observation is explained by a decrease in the electron density of the Pt clusters. This result is consistent with the infrared results. When $\mathrm{CO}$ is adsorbed on the Pt clusters, electron transfer occurs from the $\mathrm{d}$ orbitals of $\mathrm{Pt}$ to the antibonding $\pi^{*}$ orbitals of $\mathrm{CO}$, leading to a lowering of Pt electron density and the $\mathrm{CO}$ absorption frequency (from $2143 \mathrm{~cm}^{-1}$, characteristic of $\mathrm{CO}$ gas, to $2064 \mathrm{~cm}^{-1}$, characteristic of carbonyl ligands). ${ }^{34}$

$\mathrm{CO}$ adsorption is a common characterization technique used to determine the dispersion (fraction of the metal atoms exposed) of supported metal catalysts. ${ }^{35}$ The present results indicate that $\mathrm{CO}$ is not always an innocent adsorbate. Depending on the metal cluster size and hydroxyl group content of the support surface, $\mathrm{CO}$ may induce significant morphological changes in the metal, leading to inaccuracy of the dispersion measurements. The adsorption of $\mathrm{CO}$ on highly dispersed supported $\mathrm{Rh}, \mathrm{Ir}$, and $\mathrm{Ru}$ catalysts has been reported to lead to the disruption of the metal clusters, and the surface hydroxyl groups play a principal role. The reaction is described as oxidative fragmentation, and the process can be formulated in a simplified way as follows: ${ }^{36-41}$

$(1 / x) \mathrm{M}_{x}+\{\mathrm{Al}-\mathrm{OH}\}+2 \mathrm{CO}(\mathrm{g}) \rightarrow\left\{\mathrm{Al}-\mathrm{O} \mid \mathrm{M}(\mathrm{CO})_{2}+1 / 2 \mathrm{H}_{2}\right.$

where $\mathrm{M}$ represents $\mathrm{Rh}, \mathrm{Ir}$, or $\mathrm{Ru}$ and the braces refer to groups terminating an aluminum oxide surface.

(28) Balerna, A.; Bernieri, E.; Picozzi, P.; Reale, A.; Santucci, S.; Burattini, E.; Mobilio, S. Phys. Rev. 1985, B31, 5058

(29) van't Blik, H. F. J.; von Zon, J. B. A. D.; Koningsberger, D. C. J. Mol. Catal. 1984, 25, 379.

(30) Balerna, A.; Mobilio, S. Phys. Rev. 1986, B34, 2239.

(31) Lytle, F. W.; Wei, P. S. P.; Greegor, R. B.; Via, G. H.; Sinfelt, J. H. J. Chem. Phys. 1979, 70, 4849.

(32) Koningsberger, D. C. To be published.

(33) Ravenek, W.; Jansen, A. P. J.; van Santen, R. A. J. Phys. Chem. $1989,93,6445$

(34) Cotton, F. A.; Wilkinson, G. Advanced Inorganic Chemistry; Wiley: New York, 1988; p 61 .

(35) Anderson, R. B., Dawson, P. T., Eds. Experimental Methods in Catalytic Research; Academic Press: New York, 1976; Vol. 2.

(36) Cavanagh, R. R.; Yates, J. T., Jr. J. Chem. Phys. 1981, 74, 4150. (37) van't Blik, H. F. J.; van Zon, J. B. A. D.; Huizinga, T.; Vis, J. C.; Koningsberger, D. C.; Prins, R. J. Am. Chem. Soc. 1985, 107, 3139.

(38) Solymosi, F.; Novak, E.; Molnar, A. J. Phys. Chem. 1990, 94, 7250.

(39) Solymosi, F.; Rasko, J. J. Catal. 1989, 115, 107.

(40) Paul, D. K.; Yates, J. T., Jr. J. Phys. Chem. 1991, 95, 1699.

(41) Ballinger, T. H.; Yates, J. T., Jr. J. Phys. Chem. 1991, 95, 1694. 
In contrast to $\mathrm{Rh}, \mathrm{Ir}$, and $\mathrm{Ru}$ cases, no cluster disintegration has been observed for Pd as a result of $\mathrm{CO}$ adsorption. Instead, larger clusters have been formed, ${ }^{42,43}$ as observed here for Pt. The details of the chemistry whereby $\mathrm{CO}$ adsorption causes Pt cluster aggregation remain to be elucidated. Our observations and the published results ${ }^{43}$ suggest a role of surface hydroxyl groups.

The interaction between metal clusters and surface oxygen has been investigated by Lytle et al. ${ }^{18}$ The characteristic interaction between the metal and hydroxyl groups was characterized theoretically by Martens ${ }^{23}$ and experimentally by Koningsberger et al. ${ }^{21,22}$ The interaction between metal and surface hydroxyl groups is thermodynamically quite unstable; EXAFS results demonstrate that the evacuation ${ }^{44}$ of a reduced $\mathrm{Ir} / \gamma-\mathrm{Al}_{2} \mathrm{O}_{3}$ sample at $350^{\circ} \mathrm{C}$ leads to removal of $\mathrm{OH}$ groups from the metal-support interface, resulting in the disappearance of the long metal-support distance, accompanied by a structural rearrangement of the metal-support interface. Similarly, after $\mathrm{CO}$ treatment of the reduced supported $\mathrm{Pt}$ clusters, the coordination number of the long $\mathrm{Pt}-\mathrm{O}$ distance decreases, whereas that of the short $\mathrm{Pt}-\mathrm{O}$ distance is unchanged (Tables III and IV).

These results provide a confirmation of the inference that the interactions between metal clusters and surface hydroxyl groups are weak. CO molecules may replace the hydroxyl groups bonded to $\mathrm{Pt}$, or the surface energy of Pt clusters may be modified by $\mathrm{CO}$, resulting in a weakening of the interaction between $P t$ and surface hydroxyl groups.

Therefore, on the basis of the EXAFS results (Tables III and IV), the decarbonylation of $\mathrm{Pt}$ carbonyl clusters on $\mathrm{MgO}$ at 120 ${ }^{\circ} \mathrm{C}$ under vacuum and their recarbonylation are formulated very roughly as follows:

$$
\begin{aligned}
{\left[\mathrm{Pt}_{15}(\mathrm{CO})_{30}\right]^{2-} \stackrel{\mathrm{MgO}}{\longrightarrow} \mathrm{Pt}_{15}\{\mathrm{HOMg}\}_{30}\{\mathrm{OMg}\}_{15}+30 \mathrm{CO} } \\
(x / 15) \mathrm{Pt}_{15}\{\mathrm{HOMg}\}_{30}\{\mathrm{OMg}\}_{15}+0.75 x \mathrm{CO} \rightarrow \\
\mathrm{Pt}_{x}(\mathrm{CO})_{0.75 x}\{\mathrm{HOMg}\}_{0.5 x}\{\mathrm{OMg}\}_{x}
\end{aligned}
$$

Where $\{\mathrm{OMg}\}$ and $\{\mathrm{HOMg}\}$ represent the oxygen ions and hydroxyl groups of the $\mathrm{MgO}$ surface that interact with Pt clusters at distances of about $2.1-2.2$ and $2.7-2.8 \AA$, respectively.

In summary, we might speculate on the mechanism from the evidence that the metal-support interaction decreases after $\mathrm{CO}$ adsorption and the Pt clusters tend to coalesce. Since the affinity of $\mathrm{Pt}$ for $\mathrm{CO}$ is greater than that for $\{\mathrm{HOMg}\}$ groups, $\mathrm{CO}$ ligands may replace $\{\mathrm{HOMg}$ \} and loosen the interaction of the $\mathrm{Pt}$ atoms with the support. After the formation of Pt carbonyl species, the affinity of a mobile Pt carbonyl species for other Pt carbonyl species may be greater than that of Pt carbonyl species for the support. Consequently, a more stable morphology, characterized by larger, nearly hemispherical (and nonuniform) Pt clusters, may result. In contrast, the carbonyls of the less noble (more oxophilic) $\mathrm{Rh}, \mathrm{Ir}$, and $\mathrm{Ru}$ have greater affinity for the metal oxide support than Pt carbonyls do. Instead of agglomeration to give zerovalent metal clusters, the oxidative disruption of the clusters takes place, giving cationic metal complexes with surface $\mathrm{O}^{2-}$ ions and/or $\mathrm{OH}^{-}$ groups as ligands.

\section{Experimental Methods}

Materials and Sample Preparation. Sample preparation and handling were carried out with exclusion of air and moisture on a double-manifold Schlenk vacuum line or in a nitrogen-filled Braun glovebox in which the concentrations of $\mathrm{O}_{2}$ and water were typically less than 1.0 and $0.1 \mathrm{ppm}$, respectively. The solvents were dried and deoxygenated prior to use; THF and hexane were dried over sodium benzophenone ketyl, and methanol was dehydrated by distillation from $\mathrm{Mg}$ and sublimed $\mathrm{I}_{2}$. The $\mathrm{MgO}$ support (EM Science) was pretreated by heating to $400^{\circ} \mathrm{C}$ in flowing $\mathrm{O}_{2}$ (Matheson, extra dry grade) for $4 \mathrm{~h}$, followed by evacuation for $8 \mathrm{~h}$. The surface area was approximately $75 \mathrm{~m}^{2} / \mathrm{g}$. To make the supported platinum, $\left[\mathrm{Na}_{2}\left[\mathrm{PtCl}_{6}\right]\right.$ (Aesar, 99.9\%), used without further

(42) Zhang, Z.; Chen, H.; Sheu, L.-K.; Sachtler, W. M. H. J. Catal. 1991 , $127,213$.

(43) Anderson, S. L.; Mizushima, T.; Udagawa, Y. J. Phys. Chem. 1991, 95,6603 .

(44) Kampers, F. W. H.; Koningsberger, D. C. Faraday Discuss. Chem. Soc. $1990,89,137$ purification, was added to a methanol $(50 \mathrm{~mL})$ slurry of pretreated $\mathrm{MgO}$ powder $(3 \mathrm{~g})$ at room temperature. The amounts were chosen so that adsorption of all the $[\mathrm{Na}]_{2}\left[\mathrm{PtCl}_{6}\right]$ by the $\mathrm{MgO}$ would have given a solid containing $2 \mathrm{wt} \% \mathrm{Pt}$. After the reaction mixture was stirred under $\mathrm{CO}$ (Matheson, 99.99\%) at room temperature for $8 \mathrm{~h}$, a yellow-green color was observed in both the liquid and solid phases. The methanol solvent was pumped off under vacuum for $6 \mathrm{~h}$ at room temperature. The resultant yellow-green solid was transferred to the drybox for storage, and the infrared spectrum was immediately recorded.

Characterization of Extracted Surface Species by IR and UV-Visible Spectroscopy. Extraction of the surface organometallic species was performed in a $\mathrm{CO}$ environment with a saturated solution of bis(triphenylphosphoranylidene)ammonium chloride, [PPN][Cl] (Strem, 99.9\%). One gram of the sample was loaded into a Schlenk flask in a drybox. The species formed on the $\mathrm{MgO}$ surface were extracted under an atmosphere of $\mathrm{CO}$ by addition of approximately $60 \mathrm{~mL}$ of $[\mathrm{PPN}][\mathrm{Cl}]$ in a THF solution. Solution IR spectra were recorded with a Nicolet $510 \mathrm{M}$ spectrometer with a spectral resolution of $4 \mathrm{~cm}^{-1}$. The extracted solution was further diluted to about $1 / 40$ th of its original concentration. Solution UV-visible spectra were measured with a Hewlett-Packard 8425 spectrometer. The IR and UV-visible cells were designed to exclude air and moisture.

Characterization of Surface Species by DRIFTS. Diffuse reflectance infrared Fourier transform spectra (DRIFTS) of surface species were recorded with the Nicolet 510M instrument. The powder samples were loaded into the DRIFTS cell in the drybox. The cell was connected to a vacuum/gas-handling manifold for in-situ treatment. ${ }^{45}$ The decarbonylation of the sample was carried out in the cell under vacuum $(0.01-0.001$ Torr $)$. The temperature was increased at about $5^{\circ} \mathrm{C} / \mathrm{min}$ in intervals of $25^{\circ} \mathrm{C}$ and maintained for $30 \mathrm{~min}$, until finally at $100^{\circ} \mathrm{C}$ no significant peaks remained in the carbonyl stretching range, $1700-2200 \mathrm{~cm}^{-1}$. After this decarbonylation, the sample was cooled to room temperature. $\mathrm{CO}$ (flowing at $50-100 \mathrm{~mL} / \mathrm{min}$ at $1 \mathrm{~atm}$ ) was then introduced into the cell, and its flow was maintained for about $20 \mathrm{~min}$. After the $\mathrm{CO}$ treatment, the cell was evacuated to a pressure of approximately $10^{-2}-10^{-3}$ Torr, and IR spectra were again recorded.

EXAFS Spectroscopy. The EXAFS experiments were performed on $\mathrm{X}$-ray beamline $\mathrm{X}-11 \mathrm{~A}$ at the National Synchrotron Light Source at Brookhaven National Laboratory, Upton, Long Island, NY. The ring energy was $2.5 \mathrm{GeV}$ and the ring current $60-200 \mathrm{~mA}$. The Si(111) channel-cut monochromator was detuned $20 \%$ to reject higher harmonics; resolution, $\Delta E / E$, was $2.0 \times 10^{-4}$. The EXAFS spectra were recorded with the sample in a cell that allowed treatment under vacuum or in flowing gases prior to the measurements. The powder samples were pressed into wafers in a $\mathrm{N}_{2}$-filled glovebag with the wafer thickness chosen to give an absorbance of 2.5. The EXAFS measurements were made in the region of the $\mathrm{PtL}_{\text {III }}$ edge with the cell cooled by liquid $\mathrm{N}_{2}$.

The supported $\mathrm{Pt}$ sample was prepared by decarbonylation of the initially prepared platinum carbonyl at $120^{\circ} \mathrm{C}$ for $1 \mathrm{~h}$ under vacuum $(0.01-0.001$ Torr $)$. The sample was loaded into the EXAFS cell in a $\mathrm{N}_{2}$-filled glovebag and then scanned twice in the $\mathrm{N}_{2}$ environment. After data collection, the cell was allowed to warm to room temperature, and flow of $\mathrm{CO}(50-100 \mathrm{~mL} / \mathrm{min}$ at $1 \mathrm{~atm})$ was started and maintained for $0.5 \mathrm{~h}$. Then the cell was evacuated $(0.01$ Torr) and cooled to liquid nitrogen temperature, and the EXAFS spectrum was again recorded. EXAFS data for the reference materials, $\mathrm{Pt}$ foil, $\mathrm{Na}_{2} \mathrm{Pt}(\mathrm{OH})_{6}$, Ir-Al alloy, and $\left[\mathrm{Ir}_{4}(\mathrm{CO})_{12}\right]$, were measured as described separately. ${ }^{11}$

\section{Conclusions}

Surface-mediated synthesis was used to prepare $\left[\mathrm{Pt}_{15}(\mathrm{CO})_{30}\right]^{2-}$ on the surface of $\mathrm{MgO}$ powder. The bridging $\mathrm{CO}$ ligands of this supported cluster are more labile than the terminal CO ligands, and decarbonylation under vacuum commenced with the removal of the bridging $\mathrm{CO}$ ligands at $75^{\circ} \mathrm{C}$, followed by the removal of the terminal $\mathrm{CO}$ ligands at $100^{\circ} \mathrm{C}$. The decarbonylated Pt cluster is modeled as a trigonal prism to account for the EXAFS data. Readsorption of $\mathrm{CO}$ did not regenerate the original $\left[\mathrm{Pt}_{15}(\mathrm{CO})_{30}\right]^{2-}$; rather, it induced $\mathrm{Pt}$ cluster growth to give nonuniform structures resembling hemispheres.

Acknowledgment. We gratefully acknowledge the support of the National Science Foundation (Grant CTS-9012910); we also acknowledge the U.S. Department of Energy, Division of Materials Science, under Contract No. DE-FG05-89ER45384, for its role in the operation and development of Beamline X-11A at the National Synchrotron Light Source. The NSLS is supported by

(45) Zhou, P.-L.; Maloney, S. D.; Gates, B. C. J. Catal. 1991, 129, 315. 
the Department of Energy, Division of Materials Science and Division of Chemical Sciences, under Contract No. DE-AC0276CH00016. The international collaboration was supported by a NATO travel grant.
Supplementary Material Available: Figures showing raw EXAFS data and additional plots giving details of the EXAFS analysis ( 7 pages). Ordering information is given on any current masthead page.

\title{
A Test of the Utility of Plane Waves for the Study of Molecules from First Principles
}

\author{
Andrew M. Rappe, ${ }^{\dagger}$ J. D. Joannopoulos, ${ }^{\dagger}$ and P. A. Bash*, ${ }^{*}$ \\ Contribution from the Department of Physics and Chemistry and the Research Laboratory of \\ Electronics, Massachusetts Institute of Technology, Cambridge, Massachusetts 02139, and \\ Department of Chemistry, Florida State University, Tallahassee, Florida 32306. \\ Received August 19, 1991
}

\begin{abstract}
This paper studies the applicability of a plane-wave basis set for density functional calculations of the properties of molecules from first principles. The main features of the plane-wave method are described, including pseudopotentials and supercells. The results for a number of small molecules are reported. The close agreement with experiment and with a standard method of quantum chemistry calculation indicates the promise which this method holds for chemical and biochemical first-principles computations.
\end{abstract}

\section{Introduction}

Density functional theory ${ }^{1,2}$ has recently shown significant promise $^{3.4}$ as an analytical tool for studying chemical systems from first principles. Currently, the calculations of properties of molecules containing first-row elements are most commonly performed using a basis set of localized orbitals for wave function expansions. The purpose of this paper is to report results which indicate the viability of the plane-wave basis set as an alternative choice for this expansion. First we will describe the salient features of this computational method, and then we will exhibit structural results for a number of small molecules.

The plane-wave basis set has a number of extremely desirable features. The set of plane waves is complete and orthonormal. In addition, plane waves can be indexed by a single vector index, the wave vector. These two properties make finite sets of plane waves systematically improvable in a straightforward manner. A calculation is performed using a basis set of all plane waves such that each plane wave's wave vector has a magnitude less than some value, the plane-wave cutoff. Then the basis set is improved by increasing the plane-wave cutoff until the results converge. ${ }^{5,6}$ This systematic improvability provides another advantage, the numerical stability of results. Another benefit of using plane waves is that a priori knowledge of the electronic distribution is not required for the generation of the basis set. Finally, there are reliable and efficient methods for finding electronic eigenstates and atomic positions. The Car and Parrinello molecular dynamics method, ${ }^{7,8}$ because it allows simultaneous updates to wave functions and atoms, speeds up calculations significantly relative to traditional matrix diagonalization approaches. The fast Fourier transform algorithm improves the scaling of many parts of the calculation, and the conjugate gradient technique ${ }^{9,10}$ for minimizing the electronic energy makes possible the study of large molecules, whereas other minimization techniques exhibit instability as the cell size becomes very large. The scaling behavior of the various parts of the calculation is shown in Table I. A gauge of the computational time for this method is the time required to calculate the total energy and quantum-mechanical forces on the ions in a particular geometry. For the formamide molecule in a $7-\AA$ box with a plane-wave cutoff of $544.232 \mathrm{eV}(40 \mathrm{Ry})$, this cal-

\footnotetext{
${ }^{\dagger}$ Massachusetts Institute of Technology
}

Florida State University.
Table I. Scaling Properties of the LDAP-PW Method ${ }^{a}$

\begin{tabular}{ll}
\hline \multicolumn{1}{c}{ step } & \multicolumn{1}{c}{ scaling } \\
\hline Fourier transform of wave functions & $N_{\mathrm{b}} N_{\mathrm{pw}} \ln \left(N_{\mathrm{pw}}\right)$ \\
acceleration of coefficients & $N_{\mathrm{b}} N_{\mathrm{pw}} \ln \left(N_{\mathrm{pw}}\right)$ \\
forces on ions & $N_{\mathrm{b}} N_{\mathrm{i}} N_{\mathrm{pw}}$ \\
orthogonalization & $N_{\mathrm{b}} N_{\mathrm{b}} N_{\mathrm{pw}}$ \\
\hline
\end{tabular}

${ }^{a} N_{\mathrm{b}}$ is the number of filled bands (orbitals), $N_{\mathrm{i}}$ is the number of ions, and $N_{\mathrm{pw}}$ is the number of plane waves. $N_{\mathrm{pw}}$ is roughly 100 times larger than $N_{b}$, which is twice the size of $N_{\mathrm{i}}$.

culation requires approximately $450 \mathrm{CPU}$ s on a Cray-2 computer.

The chief difficulty with using plane waves as a basis set is that sharply-peaked functions require huge numbers of plane waves to converge. For this reason, expression of core electrons using plane waves is extremely difficult. Because valence electrons are orthogonalized to the core, even the expression of valence electrons is very difficult when core electrons are included in the calculation. This problem has been surmounted by the use of pseudopotentials. ${ }^{11,12}$ A pseudopotential is a weaker potential than the Coulomb potential, and it includes the effects of the core electrons implicitly. To generate a pseudopotential, a density functional calculation is normally performed on a free atom with specified electron fillings of the orbitals. A pseudopotential is then con-

(1) Hohenberg, P.; Kohn, W. Phys. Rev. 1964, 136, B864

(2) Kohn, W.; Sham, L. J. Phys. Rev. 1965, 140, A1133.

(3) For a current survey, see: Density Functional Methods in Chemistry; Springer-Verlag: New York, 1991

(4) Parr, R. G.; Yang, W. Density Functional Theory of Atoms and Molecules; Oxford: New York, 1989

(5) Ihm, J.; Zunger, A.; Cohen, M. L. J. Phys. C.: Solid State Phys. 1979, 12,4409

(6) For reviews, see: Joannopoulos, J. D. In Physics of Disordered Ma. terials; Plenum Publishing: New York, 1985. Pickett, W. Comput. Phys. Rep. 1989, 9, 115

(7) Car, R.; Parrinello, M. Phys. Rev. Lett. 1985, 55, 2471

(8) Payne, M. C.; Joannopoulos, J. D.; Allan, D. C.; Teter, M. P.; Vanderbilt, D. H. Phys. Rev. Lett, 1986, 56, 2656.

(9) Teter, M. P.; Payne, M. C.; Allan, D. C. Phys. Rev. B 1989, 40, 12255.

(10) Arias, T. A.; Payne, M. C.; Joannopoulos, J. D. Phys. Rev. B 1992, 45,1538

(11) Phillips, J. C. Phys. Rev. 1958, /12,685

(12) Cohen, M. L.; Heine, V. Solid State Phys. 1970, 24, 37 